\title{
The Library of Congress View on Its Relation to the ALA MARC Advisory Committee
}

Henriette D. AVRAM: MARC Development Office, Library of Congress.

This paper is a statement of the Library of Congress' recommendation that a MARC advisory committee be appointed within the present structure of the RTSD/ISAD/RASD Committee on Representation in Machine-Readable Form of Bibliographic Information (MARBI) and describes the Library's proposed relation to such a committee. The proposals and recommendations suggested were adopted by the MARBI Committee during its deliberations at ALA Midwinter, January 1974, and are now in effect.

\section{INTRODUCTION}

During ALA Midwinter, January 1973, the Library of Congress (LC) suggested to the RTSD/ISAD/RASD Committee on Representation in Machine-Readable Form of Bibliographic Information that a MARC advisory committee be formed to work with the MARC Development Office regarding changes made to the various MARC formats. The primary interest of the committee would be the serial and monograph formats, though the committee should have interest in and responsibility for reviewing changes in any of the MARC formats to insure that the integrity and compatibility of MARC content designators are preserved. The MARBI Committee decided that it would be the MARC advisory committee and asked that a paper be prepared proposing how such a committee would operate in relationship to the MARC Development Office.

Prior to a discussion of MARC changes, it appears appropriate to make certain basic statements regarding MARC changes and the difficulties experienced by the MARC Development Office in evaluating the significance of a change for the MARC subscriber.

It would be naive to assume, in a dynamic situation, that even in the best of all worlds a MARC subscriber would never have to do any reprogramming. Changes in procedures, changes in cataloging, experience in providing the knowledge for more efficient ways to process information, additional requirements from users, etc., have always been factors creating the 
need to both modify and/or expand an automated system. Programming installations always require personnel to maintain ongoing systems. Situations creating changes locally must exist and, likewise, they also exist at LC.

Staff of the MARC Development Office give serious consideration to every proposed MARC change and its impact on the MARC subscribers. However, it must be realized that it is not possible to evaluate fully the impact of each change because the significance of a change is directly dependent on the use made of the elements of the record and the programming techniques used by each subscriber. MARC staff cannot possibly know the details of use and programming techniques and capabilities at every user installation.

Each MARC subscriber evaluates a change in light of his operational requirements. Since the uses made of the data are varied among users, there is rarely a consensus as to the pros and cons of a change. MARC staff are aware of the expenses imposed by changes to software and have made an attempt to solicit preferences in some cases for one technique over another from MARC subscribers when changes were required. In the case of the ISBD implementation, ten replies were received from questions submitted to the then sixty-two MARC users.

The remainder of this paper describes what is included in the term "change," the various stimuli that initiate changes, and recommendations of how LC and the MARC advisory committee should interact in regard to changes.

The appendix summarizes in chart form the addenda to Books: $A$ MARC Format since the initiation of the MARC service. An examination of the chart will reveal that the number and the types of changes have not been too significant.

\section{MARC CHANGES}

The term "change" is used throughout this paper in the broad sense, i.e., the term includes additions, modifications, and deletions of content data (in both fixed and variable fields) and content designators (tags, indicators, and subfield codes) made to the format as well as additions, modifications, and deletions made to the tape labels. The concern is with changes made to all records where applicable or groups of records but not with the correction or updating of individual records as part of the MARC Distribution Service.

Changes as described above fall into several broad types:

1. Addition of new fields, indicators, or subfield codes to the format.

2. Implementation of already defined but unused tags, indicators, subfield codes, or fixed fields.

3. Modification of content data of fields (fixed and variable).

4. Changes in style of content in records, e.g., punctuation.

5. Cessation in use of existing fields, indicators, and subfield codes. 
The following paragraphs are divided into two sections. Section "a" describes the stimulus for a change and the rationale for making it. Section " $b$ " describes the LC position regarding the change and, where applicable, a recommendation to the MARC advisory committee.

Changes made to MARC records may be divided into the following categories:

Category 1: Changes resulting from a change in cataloging rules or systems.

a. Cataloging rules or systems fall into two distinct types: those made in consultation with ALA (Resources \& Technical Services Division/Cataloging \& Classification Section/Descriptive Cataloging Committee), and those made by the Subject Cataloging Division to the subject cataloging system without consultation with ALA.

LC follows AACR. Since the MARC record is the record used for LC bibliographical control as well as the source record for the LC printed card and LC book catalogs (for those items presently within the scope of MARC), cataloging changes (descriptive and subject) are necessarily reflected in MARC. If the cataloging change is such that the retrospective records can reasonably be modified by automated techniques, these records are modified to reflect the change. Prior to MARC, this updating could not be provided to subscribers to LC bibliographic products and is one of the advantages of a machine-readable service. It has the effect of maintaining a consistent data base for all MARC users.

b. Changes made in cataloging rules or systems will be made by the appropriate agencies. Once changes in cataloging rules have been made by the ALA (RTSD/CCS/DCC) committee, LC will consult with the MARC advisory committee with respect to their implementation in those cases affecting the MARC format. Wherever possible, depending upon resources available, the number of records affected, and the type of change, the retrospective files will be updated and made available in one of two ways: if the number of records is small (to be decided by LC), the records will be distributed as corrections through the normal channels of the MARC Distribution Service. If the number of records is large, the records will be sold by the LC Card Division.

Category 2: Changes made to satisfy a requirement of the Library of Congress.

a. Since LC uses the MARC records for its own purposes, situations do arise in which LC has a requirement for a change. In most cases, LC feels that the change would also be beneficial to the users. Under these circumstances LC has carefully evaluated the im-

*Format change is used in this context to mean a change affecting the tags, indicators, subfield codes, addition or deletion of fixed fields, or change to the leader. 
plication of the change to the MARC subscribers and, in some cases, solicited their preferences and advice.

b. If $\mathrm{LC}$ has a requirement to make a change to MARC, the proposed change and the reason for the change will be referred to the MARC advisory committee. The MARC advisory committee will solicit opinions from MARC users as to whether or not to include the change in the MARC Distribution Service, and LC will abide by the committee's recommendation. If this decision is not to include the change, LC will implement the change only in its own data base. $\dagger$

Category 3: Changes made to satisfy subscribers' requests.

a. Subscribers sometimes request that a change be made to a MARC record. Where possible, within the limitation of LC resources, these requests are complied with. $\mathrm{LC}$, when considering such a request, has sought the opinion of the MARC subscribers, and if sufficient numbers of users were interested in the change, the change was implemented.

b. Changes requested by subscribers will be evaluated by LC, and if considered possible to implement, the proposed change will be submitted by LC to the MARC advisory committee to solicit opinions from MARC users. If the committee recommends, LC will implement the change.

Category 4: Changes made to support international standardization.

a. LC plays a significant role in international activities in the area of machine-readable cataloging records. Much of the future expansion of MARC depends upon standards in formats, data content, and cataloging. In all these activities, LC firmly supports AACR and current MARC formats.

Occasionally, in order to arrive at complete agreement with agencies in other countries, it becomes necessary for all to compromise. However, in all cases LC does not agree to changes in cataloging rules until the recommendation has been approved by the appropriate ALA committee.

b. Changes resulting from international meetings will fall principally into two areas:

1. Cataloging-if the change required is the result of a change in cataloging rules and the ALA (RTSD/CCS/DCC) has approved the AACR modifications, the MARC change falls into Category 1.

2. All other changes affecting the format-since LC is the agency in the U.S. that will exchange machine-readable bibliographic records with other national agencies, LC will consider these

$\dagger$ An exception to this statement will be those changes to LC practice which must be reflected on cards and in the MARC record and which cannot exist in optional form. An example of the above would be abolition of the check digit in the LC card number. 
changes an internal LC requirement; therefore, they can be considered under the proposal described in Category 2. LC will submit the proposed changes to the MARC advisory committee.

Category 5: Changes made to expand the MARC program to include additional services.

a. If the MARC service were static, changes to expand the service would not be possible. An example of an additional service is the Cataloging in Publication data available on MARC tapes. Since these cataloging data are available four to six months prior to the publication of the item, it was determined to be of value to MARC subscribers and changes were made to the MARC record to make these data available in machine-readable form.

b. If a new service is under consideration at LC that will cause a change to MARC records, e.g., Cataloging in Publication, LC will submit the proposal to the MARC advisory committee for their action as described in Category 2.

\section{OTHER LC RECOMMENDATIONS FOR THE MARC ADVISORY COMMITTEE}

1. Time frame for changes. In order to prevent consultation on changes from taking an inordinate length of time, LC proposes that the MARC advisory committee be given two months to solicit comments from MARC users, to arrive at a consensus, and to respond to proposed changes. If there is no response during that time, LC will implement the proposed change. LC will notify the MARC subscribers two months prior to including the change in the MARC Distribution Service.

2. Consultation with the MARC advisory committee. The MARC Development Office will submit the recommendation for change and any other information required to evaluate the change to the MARC advisory committee. The MARC advisory committee will be responsible for submitting the proposal to the MARC users and notifying the MARC Development Office of the committee's recommendation.

3. Test tapes. The MARC advisory committee, on consultation with the MARC Development Office, will consider the requirement for a test tape to reflect the change made to the MARC record (the requirement for a test tape is dependent on the type of change made).

APPENDIX A

Addenda to Books: A MARC Format

\begin{tabular}{llll}
\hline \multicolumn{1}{c}{ Stimulus for Change } & Date & Change & Comments \\
\hline \hline $\begin{array}{l}\text { 1. Cataloging Rules and } \\
\text { Cataloging System } \\
\text { Changes }\end{array}$ & 1972 & $\begin{array}{l}\text { U.S./Gt. Brit. changed to } \\
\text { United States and Great } \\
\text { Britain. }\end{array}$ & $\begin{array}{l}\text { Change made to facilitate } \\
\text { machine filing. }\end{array}$ \\
\cline { 2 - 4 }
\end{tabular}


APPENDIX A-Continued

\begin{tabular}{|c|c|c|c|}
\hline Stimulus for Change & Date & Change & Comments \\
\hline & 1972 & ISBD. & $\begin{array}{l}\text { Cataloging change based on } \\
\text { an international agreement. }\end{array}$ \\
\hline & 1973 & ISBD-additional information. & \\
\hline 2. Subscribers Requests & 1972 & $\begin{array}{l}\text { Government Publication Code } \\
\text { added to Fixed Field. }\end{array}$ & \\
\hline \multirow[t]{4}{*}{$\begin{array}{l}\text { 3. Initiated at LC: } \\
\text { a. Addition or Deletion } \\
\text { of Fields }\end{array}$} & 1969 & $\begin{array}{l}\text { Abolishment of } 653 \text {-Political } \\
\text { Jurisdiction (Subject) and } \\
750 \text {-Proper Name Not } \\
\text { Capable of Authorship. }\end{array}$ & $\begin{array}{l}\text { These little-used fields proved } \\
\text { difficult to define and of little } \\
\text { value. }\end{array}$ \\
\hline & 1970 & $\begin{array}{l}\text { Addition of Encoding Level to } \\
\text { Leader. }\end{array}$ & $\begin{array}{l}\text { Implemented for use for } \\
\text { RECON records. }\end{array}$ \\
\hline & 1970 & $\begin{array}{l}\text { Addition of Geographic Area } \\
\text { Code field, tag } 043 \text {. }\end{array}$ & $\begin{array}{l}\text { This field has been widely } \\
\text { used by LC and subscriber } \\
\text { libraries. }\end{array}$ \\
\hline & 1971 & $\begin{array}{l}\text { Addition of Superintendent of } \\
\text { Documents field, tag } 086 .\end{array}$ & $\begin{array}{l}\text { Information added to LC } \\
\text { catalog cards (and thus to } \\
\text { MARC records) at the request } \\
\text { of outside libraries. }\end{array}$ \\
\hline \multirow[t]{2}{*}{$\begin{array}{l}\text { b. Additions of Indicators } \\
\text { or Subfields }\end{array}$} & 1971 & Addition of Filing Indicators. & $\begin{array}{l}\text { Information needed to allow } \\
\text { LC to ignore initial articles in } \\
\text { arranging its computer- } \\
\text { produced book catalog. }\end{array}$ \\
\hline & 1972 & $\begin{array}{l}\text { Addition of " } q \text { " subfield to } \\
\text { fields for conferences entered } \\
\text { under place. }\end{array}$ & $\begin{array}{l}\text { Subfield needed to enable LC } \\
\text { to file conferences entered } \\
\text { under place correctly. }\end{array}$ \\
\hline \multirow[t]{7}{*}{$\begin{array}{l}\text { c. Addition or change of } \\
\text { codes or data to } \\
\text { existing fields }\end{array}$} & 1969 & $\begin{array}{l}\text { Code added to Modified } \\
\text { Record Indicator in fixed field } \\
\text { to indicate shortened records. }\end{array}$ & \\
\hline & 1969 & $\begin{array}{l}\text { Code for phonodiscs added to } \\
\text { Illustration fixed field. }\end{array}$ & \\
\hline & 1970 & $\begin{array}{l}\text { Code added to Modified } \\
\text { Record Indicator in fixed field } \\
\text { to indicate that the dashed-on } \\
\text { entry on the original LC card } \\
\text { was not carried in MARC } \\
\text { record. }\end{array}$ & \\
\hline & 1971 & $\begin{array}{l}\text { "Questionable Condition" } \\
\text { codes deleted from Country } \\
\text { of Publication code. }\end{array}$ & \\
\hline & 1971 & $\begin{array}{l}\text { Geographic Area Code. } \\
\text { Guidelines for implementation } \\
\text { modified slightly and } 23 \text { new } \\
\text { codes added. }\end{array}$ & \\
\hline & 1971 & $\begin{array}{l}\text { Microfilm call numbers } \\
\text { carried in LC call number field. }\end{array}$ & $\begin{array}{l}\text { Description of what such call } \\
\text { numbers looked like. }\end{array}$ \\
\hline & 1971 & $\begin{array}{l}\text { Abolished LC card number } \\
\text { check digit. }\end{array}$ & $\begin{array}{l}\text { Numbers available using } \\
\text { check digit too limited. }\end{array}$ \\
\hline
\end{tabular}


APPENDIX A-Continued

\begin{tabular}{|c|c|c|c|}
\hline Stimulus for Change & Date & Change & Comments \\
\hline \multirow[t]{3}{*}{$\begin{array}{l}\text { d. Explanations or } \\
\text { Corrections }\end{array}$} & 1970 & $\begin{array}{l}\text { Use of "b" subfield with } \\
\text { Topical Subjects (Field 650) } \\
\text { and Geographic Subjects } \\
\text { (Field 651). }\end{array}$ & $\begin{array}{l}\text { Subfield and its use inad- } \\
\text { vertently omitted from Books: } \\
\text { A MARC Format. It occurs } \\
\text { rarely in MARC records. }\end{array}$ \\
\hline & 1971 & $\begin{array}{l}\text { Use of "Revision date" as } \\
\text { suffix to LC card number. }\end{array}$ & $\begin{array}{l}\text { Explanation of what this in- } \\
\text { formation means at LC and } \\
\text { how subscribers use it. }\end{array}$ \\
\hline & 1971 & $\begin{array}{l}\text { Indicators used with } \\
\text { Romanized title. }\end{array}$ & $\begin{array}{l}\text { Explanation of use of indi- } \\
\text { cators with this field omitted } \\
\text { from Books: A MARC Format. }\end{array}$ \\
\hline e. Changes to labels & 1972 & $\begin{array}{l}\text { Change to label to reflect new } \\
\text { computer system at LC. }\end{array}$ & \\
\hline \multirow[t]{3}{*}{$\begin{array}{l}\text { 4. National and } \\
\text { International Agreement }\end{array}$} & 1970 & $\begin{array}{l}\text { Standard Book Number ( } 9 \\
\text { digits) changed to Inter- } \\
\text { national Standard Book } \\
\text { Number ( } 10 \text { digits) to con- } \\
\text { form to an international } \\
\text { standard. }\end{array}$ & \\
\hline & 1971 & $\begin{array}{l}\text { Entry Map added to Leader to } \\
\text { conform to national standard. }\end{array}$ & $\begin{array}{l}\text { Adoption of ANSI Z39 Format } \\
\text { for Exchange of Bibliographic } \\
\text { Information Interchange. }\end{array}$ \\
\hline & 1971 & $\begin{array}{l}\text { Change to label to conform to } \\
\text { ANSI standard. }\end{array}$ & \\
\hline \multirow[t]{2}{*}{ 5. New Services at LC } & 1969 & $\begin{array}{l}\text { Changes to label and status } \\
\text { codes for cumulated tapes. }\end{array}$ & $\begin{array}{l}\text { To provide for cumulative } \\
\text { quarterly and semiannual } \\
\text { tapes. }\end{array}$ \\
\hline & 1971 & $\begin{array}{l}\text { CIP records-addition of codes } \\
\text { to Encoding Level and } \\
\text { Record Status. }\end{array}$ & \\
\hline
\end{tabular}

